\title{
Anti-adenovirus activity, antioxidant potential, and phenolic content of dried flower buds of Syzygium aromaticum extract in HEp2 cell line
}

\author{
Mohammad-Taghi MORADI, Ali KARIMI, Somayeh ALIDADI, Leila HASHEMI
}

\begin{abstract}
The aim of this study is to evaluate in vitro anti-adenovirus property, antioxidant potential, and total phenolic content of dried flowers buds of Syzygium aromaticum crude extract. The crud extract was prepared and its anti-adenovirus activity was investigated on HEp2 cell line using MTT (3-[4,5-dimethylthiazol-2-yl]-2,5-diphenyltetrazolium bromide) assay. The 2,2-diphenyl-1-picrylhydrazyl (DPPH) assay, Folin-Ciocalteu method and aluminum chloride colorimetric method was used to determine antioxidant activity, total phenol content, flavonoids and flavonols content of the extract, respectively. Based on results, the $50 \%$ cytotoxicity concentration $\left(\mathrm{CC}_{50}\right)$ and the $50 \%$ inhibitory concentration
\end{abstract}

$\left(\mathrm{IC}_{50}\right)$ of the extract were $97.66 \pm 11.4$ and $4.73 \pm 1.6 \mu \mathrm{g} / \mathrm{ml}$, respectively, with the selectivity index (SI) of 20.64. The crud extract inhibited adenovirus replication in post-adsorption step $(\mathrm{p}<0.05)$. The extract showed remarkable scavenging activity with $\mathrm{IC}_{50}$ values of $10.05 \pm 1.93 \mu \mathrm{g} / \mathrm{ml}$. Total phenolic, flavonoid and flavonol content of the crude extract was $255.8 \pm 3.95$ $\mathrm{mg} \mathrm{GAE} / \mathrm{g}, 63.9 \pm 2.35 \mathrm{mg} \mathrm{RUT} / \mathrm{g}$ and $62 \pm 2.35 \mathrm{mg} \mathrm{RUT} / \mathrm{g}$, respectively. The results of the present study indicated that $S$. aromaticum crude extract exhibited anti-adenovirus activity with inhibitory effect on adenovirus replication could be considered as a potential anti-adenovirus agents.

Keywords: Antiviral; clove; Syzygium aromaticum; Adenovirus; antioxidant activity, Phenolic content

\begin{abstract}
Mohammad-Taghi Moradi, Ali Karimi
Medical Plants Research Center, Basic Health Sciences Institute, Shahrekord University of Medical Sciences, Shahrekord, Iran
\end{abstract}

Somayeh Alidadi

Clinical Biochemistry Research Center, Basic Health Sciences Institute, Shahrekord University of Medical Sciences, Shahrekord, Iran

Leila Hashemi

Cellular and Molecular Research Center, Basic Health Sciences Institute, Shahrekord University of Medical Sciences, Shahrekord, Iran

Corresponding Author:

Ali Karimi

e-mail: rakarimi1342@gmail.com

Submitted / Gönderilme: 14.02.2017 Revised / Düzeltme: 05.04.2017 Accepted / Kabul: 12.04 .2017

How to cite this article: Moradi MT, Karimi A, Alidadi S, Hashemi L. Antiadenovirus activity, antioxidant potential, and phenolic content of dried flower buds of Syzygium aromaticum extract in HEp2 cell line Marmara Pharm J 2017; 21 (4): 852-859

\section{Introduction}

Human population experience viral diseases frequently around the word and many of these viral infections remained to be treated or pose resistant to antiviral drugs [1-3]. Human adenovirus is associated with a wide range of human diseases including conjunctivitis, gastroenteritis, hepatitis, myocarditis, and pneumonia. This virus causes diseases mostly in children under 5 years of age which are generally self-limiting. However, adenovirus associated severe and life-treating infections occurred particularly in immunocompromised patients $[4,5]$. Also, adenoviral conjunctivitis with symptoms such as excess lacrimation, conjunctival injection, and photophobia is a common form of conjunctivitis among adult and children population $[6,7]$.

There are some anti-viral agents used for treatment of adenovirus infections such as Ribavirin and Cidofovir, with apparently little clinical efficacy and variable outcomes [5, 8, 9]. Cidofovir shows significant nephrotoxicity and limited bioavailability which leads to development of its derivatives. However, the efficacy of these compounds is still being 
studied $[10,11]$. Therefore, in light of the growing number of immunosuppressed patients, it is necessary to develop alternative anti-adenovirus treatments.

Herbs and herbal drugs are used to treat human diseases in different countries [12-14]. Moreover, they have been developed to be used for therapeutic purposes or promising results have been obtained about them [15-22].

Clove (Syzygium aromaticum (L.) Merr. \& L.M.Perry) is the aromatic dried flower buds of a tree in the family Myrtaceae. S. aromaticum oil is frequently used in perfumery and medicine, but mostly in flavorings. The dried flower buds of S. aromaticum, called Mikhak in Persian, is a drug of Far East, used as a verminfuge, antibacterial, and toothache-relieving agent [23].

The different species of $S$. aromaticum contain a wide spectrum of important chemical compounds such as sesquiterpenes [24], tannins [25], triterpenoids [26] and a phenolic compound called eugenol (4-allyl-2methoxyphenol). Eugenol seems to act as antioxidant, anticarminative, antispasmodic, antiseptic, and antimicrobial agent $[27,28]$. Also, S. aromaticum has been shown to have antimutagenic property. $S$. aromaticum has been shown to have both antiviral and antibacterial effects [29]. To the best of our knowledge, to date, there has been no report on the antiadenovirus activity of dried flower buds of Syzygium aromaticum extract and its mine compounds eugenol. The aim of this study is to evaluate in vitro anti-adenovirus property, antioxidant potential, and total phenolic content of S. aromaticum crude extract.

\section{Materials and Methods}

\section{Preparation of hydroalcoholic extract}

The dried flower buds of Syzygium aromaticum was purchased from a local market. Then, genus and species of the plant were identified and confirmed in Herbarium of Medical Plants Research Center of Shahrekord University of Medical Sciences, Iran (Herbarium number: 425). Afterwards, $100 \mathrm{~g}$ of S. aromaticum powder was dissolved in $70 \%$ ethyl alcohol $(400 \mathrm{~mL})$, kept for $96 \mathrm{hr}$ at room temperature (RT) and then, filtered, concentrated using rotary evaporator under nearly vacuum pressure at $40^{\circ} \mathrm{C}$, and kept in the sterile bottles at cold temperature. Then, the extract was suspended in dimethyl sulphoxide (DMSO) and Phosphate-Buffered Saline (PBS) at $37^{\circ}$, filtered (Millipore $0.22 \mu \mathrm{m}$ ) and the prepared stock solution $(25 \mathrm{mg} / \mathrm{mL})$ was kept at $4^{\circ} \mathrm{C}$ until to be used in the next experiments. The remaining DMSO (maximal 0.2\%) has no cytotoxic effect on the cells [30].

\section{Measuring free radical scavenging activity}

The extract's free radical scavenging activity was investigated according to the 2,2-diphenyl-1-picrylhydrazyl (DPPH) method with certain modifications [31]. Briefly, different amounts of the extract and methanol were introduced into $0.3 \mathrm{mg} / \mathrm{mL}$ methanolic $\mathrm{DPPH}$ solution to a final volume of $3.0 \mathrm{~mL}$ and incubated for $15 \mathrm{~min}$ at RT. Next, the solution absorbance was read at $517 \mathrm{~nm}$ by a UV-VIS spectrophotometer (UNICO 2100: USA). Low absorbance of the mixture represented high free radical scavenging activity. Butylated hydroxytoluene (BHT) was considered to be positive control. DPPH-induced inhibition of free radical was measured according to this protocol: Antiradical activity $(\%)=[($ A control $-\mathrm{A}$ sample $) / \mathrm{A}$ control $] \times 100$. The $\mathrm{IC}_{50}$ value was defined as the antioxidant concentration required to scavenge the initial DPPH concentration by $50 \%$, and calculated according to linear regression of plots of the antiradical activity percentage against the tested compounds' concentrations. Each experiment was performed in triplicate.

\section{Determination of total phenolic, flavonoid and flovonoid content}

The S. aromaticum extract total phenolic content was measured by Folin-Ciocalteu method [32, 33]. Briefly, $0.2 \mathrm{~mL}$ of the diluted sample was added to $1 \mathrm{~mL}$ of $10 \%(\mathrm{v} / \mathrm{v})$ FolinCiocalteu reagent and kept for 3-8 $\mathrm{min}$ at RT. Subsequently, $0.8 \mathrm{~mL}$ of $7.5 \%(\mathrm{w} / \mathrm{v})$ sodium carbonate solution added to the mixture and kept in total darkness for $30 \mathrm{~min}$. the absorbance of the reaction mixture was measured at $765 \mathrm{~nm}$, using a UVVIS spectrophotometer (UNICO 2100: USA). Amounts of total phenolic were calculated using a Gallic acid calibration curve. The results were expressed as milligrams of Gallic acid equivalents per gram of extract powder (mg GAE/g).

The total flavonoid content of the extract was measured as previously described [32]. In summary, $0.2 \mathrm{~mL}$ of diluted plant material was separately mixed with $1.2 \mathrm{~mL}$ of $5 \%$ $(\mathrm{w} / \mathrm{v})$ potassium acetate and $0.2 \mathrm{~mL}$ of $2 \%(\mathrm{w} / \mathrm{v})$ aluminum chloride. After incubation at RT for $40 \mathrm{~min}$, the reaction mixture absorbance was read at $415 \mathrm{~nm}$ by a UV-VIS spectrophotometer (UNICO 2100: USA). The results were expressed in milligrams of Rutin equivalents per gram of extract powder (mg RUT/g) with reference to the standard curve, which was plotted under the same conditions. 
The total Flavonols content of the extract was measured as previously reported method (21). Briefly, $0.2 \mathrm{ml}$ of diluted plant material $(1 \mathrm{mg} / \mathrm{ml}$ in methanol $60 \%), 0.2 \mathrm{ml}$ of $2 \%$ (w/v) aluminum chloride and $1.2 \mathrm{ml}$ of $5 \%$ sodium acetate. Following incubation at room temperature (RT) for 2.5 hours, the absorbance of the reaction mixture was read at $440 \mathrm{~nm}$ using a UV-VIS spectrophotometer (UNICO 2100: USA). The results were expressed in milligrams of Rutin equivalents per gram of extract powder (mg RUT/g) by comparison with the standard curve, which was made in the same condition.

\section{Cell and Virus}

HEp2 (Cervical adenocarcinoma; NCBI_Iran Cat\# C144) cells was purchased from Pasteur Institute of Iran. The cells were grown in Dulbecco's Modified Eagle's Medium (DMEM; Gibco, USA) supplemented with 10\% fetal bovine serum (FBS; Gibco, USA), $0.02 \%$ (v/v) amphotericin B and $1 \%(\mathrm{v} / \mathrm{v})$ Pen/Strep (Gibco, USA) under $37^{\circ} \mathrm{C}$ in $5 \% \mathrm{CO}_{2}$. A similar medium containing 1.5\% FBS was used for antiviral assays and cytotoxicity. Adenovirus (type 5) was provided by the Faculty of Health, Tehran University of Medical Sciences. Virus stock was prepared with infection of confluent monolayer HEp2 cells in $75 \mathrm{~cm}^{2}$ culture flasks by DMEM medium with $1.5 \% \mathrm{FBS}$, under $37^{\circ} \mathrm{C}$ in $5 \% \mathrm{CO}_{2}$. Virus titer was calculated by cytopathic effect (CPE) of adenovirus in HEp2 cell and expressed as the 50\% tissue culture infective dose $\left(\mathrm{TCID}_{50}\right)$ per $1 \mathrm{~mL}$ [34].

\section{Cytotoxicity assay}

Before examination of anti-adenovirus activity, the extract's cytotoxic effect was measured. Briefly, HEp2 were seeded onto 96-well plates with 8000 cells/well concentration with $100 \mu \mathrm{l} /$ well final volume. Following the incubation at $37^{\circ} \mathrm{C}$ with $5 \% \mathrm{CO}_{2}$ for $24 \mathrm{~h}$, the overlay medium of the confluent monolayer was removed and the cells were incubated with $200 \mu \mathrm{L} /$ well of various doses of the extract (in triplicate) for 4 days under $37^{\circ} \mathrm{C}$ with $5 \% \mathrm{CO}_{2}$. Cell viability was determined by the cells' ability to cleave the tetrazolium salt MTT [3-(4,5-dimethylthiazol-2-ol)-2,5-diphenyltetrazolium bromide)] (Sigma, USA), by mitochondrial enzyme succinate dehydrogenase which develops a formazan blue color product. The protocol described earlier was followed $[30,34]$. Briefly, the supernatants were removed from the wells and $50 \mu \mathrm{L}$ of an MTT (Sigma, USA) solution $(1 \mathrm{mg} / \mathrm{mL}$ in PBS) was added to each well. The plates were incubated for $4 \mathrm{~h}$ under $37^{\circ} \mathrm{C}$ and then the supernatants were removed and $100 \mu \mathrm{L}$ of DMSO (Samchun, Korea) was added to the wells for dissolving the MTT crystals. The plates were placed on a rotator for $15 \mathrm{~min}$ and the absorbance was read on an enzyme-linked immunosorbent assay (ELISA) reader (STATA FAX 2100, USA) at $570 \mathrm{~nm}$ wavelength. The data were expressed as toxicity percentage calculated according to the formula below: Toxicity $(\%)=[100-($ At $/ A s)] \times 100 \%$, where At and As refer to the absorbance of the test substance and the solvent control, respectively $[30,35]$. The $\mathrm{CC}_{50}$ was defined as the cytotoxic concentration of the crude extract according to regression analysis.

\section{Antiviral assay}

Antiviral activity of the extract was evaluated by inhibitory activity assay according to MTT method, as it has already been described [30]. Briefly, non-cytotoxic concentrations of the extract under the $\mathrm{CC}_{50}$ value were used to investigate their ability to inhibit CPE of adenovirus in tissue culture. $100 \mu \mathrm{L}$ $\left(100 \mathrm{TCID}_{50}\right)$ virus suspension was introduced into confluent HEp2 cell monolayer in a 96-well plate and incubated at $37^{\circ} \mathrm{C}$ for about two hours to absorb virus. Thereafter, serial twofold dilutions prepared from non-toxic dose of the extract were added and tested in triplicate. For negative or cell control, only DMEM containing 1.5\% FBS was added to the cells. As positive control, the cells were infected with an equal concentration of virus but without addition of the extract. The plates were incubated under $37^{\circ} \mathrm{C}$ in a humidified $\mathrm{CO} 2$ atmosphere for 4 days.

Cell viability was calculated using previously described MTT assay [30]. The data were expressed as the percentage of inhibition according to the following formula:

Antiviral activity (\%)=[(Atv-Acv)/(Acd-Acv) $] \times 100 \%$, where Atv, Acv, and Acd represent the absorbance of the tested compounds on virus infected cells, the absorbance of the virus control, and the absorbance of the cell control, respectively. The experiment was performed in triplicate. The $\mathrm{IC}_{50}$ was determined using a curve that related inhibition to the extract concentration. Selectivity index (SI), as a marker of antiviral activity, was determined to be $\mathrm{CC}_{50} / \mathrm{IC}_{50}$ ratio.

\section{Mode of antiviral activity}

To evaluate the mode of antiviral action of the S. aromaticum extract, confluent monolayer cells were treated with the extract in four different manners; 1) pretreated prior to infection $2 \mathrm{~h}$ at $37^{\circ} \mathrm{C}$ (pretreatment of cell); 2) only during the adsorption period (adsorption); 3) after adsorption and 


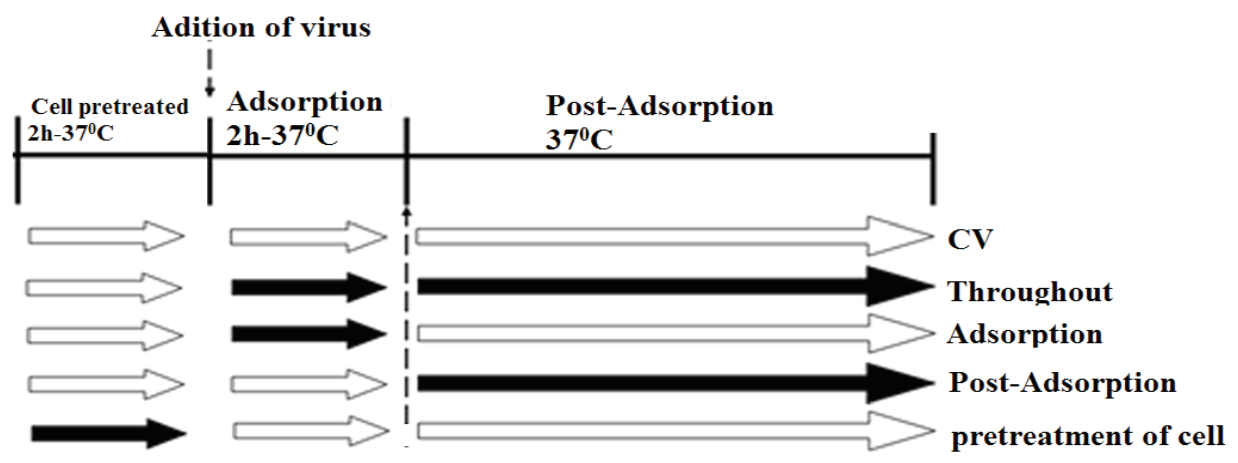

Inoculum removal

Figure 1. Pattern of extract addition during adsorption and post-adsorption stages of the virus: Open and black arrows represent the absence and presence of extract, respectively. CV: Control Virus

until the completion of the experiment (post-adsorption); and 4) throughout and after the adsorption. To implement these experiments, $90 \%$ confluent cells were pretreated with the extract before infection for $2 \mathrm{~h}$ at $37^{\circ} \mathrm{C}$ (pretreatment of cell) then cells were infected with $100 \operatorname{TCID}_{50}(100 \mu \mathrm{L} /$ well $)$ of the virus in the presence or absence of the extract and incubated again at $37^{\circ} \mathrm{C}$ for about 2 hours for adsorption of the viral particles to the cells (adsorption). Subsequently, the supernatant was separated and the medium by $1.5 \%$ FBS with or without the extract was replaced, and incubated at $37^{\circ} \mathrm{C}$ and 5\% CO2 for 4 days. Cell viability was also determined using previously described MTT assay. The experiment was carried out in triplicate and the $\mathrm{IC}_{50}$ and SI was determined for any individual experiment.

\section{Statistical analysis}

All experiences were conducted in triplicate. The $\mathrm{IC}_{50}$ and $\mathrm{CC}_{50}$ values were calculated by dose-response analyses and related models with regression probit procedure by SPSS. $P$ values of less than 0.05 were considered statistically significant.

\section{Results}

\section{Antioxidant capacity, total phenolic, flavonoid and flavonol content}

For standardization of the extract, antioxidant capacity, total phenolic, flavonoid and flavonol content in S. aromaticum extract were measured. Total phenolic, flavonoid and flavonol content of the crude extract was $255.8 \pm 3.95 \mathrm{mg} \mathrm{GAE} / \mathrm{g}$, $63.9 \pm 2.35 \mathrm{mg} \mathrm{RUT} / \mathrm{g}$ and $62 \pm 2.35 \mathrm{mg} \mathrm{RUT} / \mathrm{g}$, respectively. The crude extract had $\mathrm{IC}_{50}$ values of $10.05 \pm 1.93 \mu \mathrm{g} / \mathrm{mL}$. The results were expressed with reference to $\mathrm{BHT}$, a reference standard with $\mathrm{IC}_{50}$ of $25.41 \pm 1.89 \mu \mathrm{g} / \mathrm{mL}$ (Table 1). The results showed that the more concentration of the extract, the more scavenging effect of free radicals.

Table 1. DPPH radical-scavenging activity of the Syzygium aromaticum extract

\begin{tabular}{llll}
\hline Sample & Concentration $(\mu \mathrm{g} / \mathrm{mL})$ & $\begin{array}{l}\text { Scavenging of DPPH } \\
\text { radical activity inhibition } \\
(\%)(\text { main } \pm \text { SEM) }\end{array}$ & $\begin{array}{l}\text { DPPH-radical scavenging activity } \mathrm{IC}_{50}(\mu \mathrm{g} / \\
\mathrm{mL})\end{array}$ \\
\hline & 80 & $100 \pm 1.8$ & $10.05 \pm 1.93$ \\
S.aromaticum extract & 40 & $97.25 \pm 2.2$ & \\
& 30 & $87.2 \pm 2.6$ & $21.7 \pm 2.3$ \\
& 20 & $45.7 \pm 1.9$ & $25.41 \pm 1.89$ \\
BHT & 50 & $90.8 \pm 1.5$ & $78.3 \pm 1.2$ \\
& 40 & $55.5 \pm 0.7$ & \\
\hline
\end{tabular}

The results were presented as mean ( \pm standard mean error) value of the three assays. BHT: Butylated hydroxytoluene, DPPH: 1,1-Diphenyl-2-picrylhydrazyl. 


\section{Cytotoxicity and Anti-adenovirus activity of $S$. aromaticum extracts on HEp2 cells}

In the present study, in vitro anti-adenovirus activity of $S$. aromaticum hydroalcoholic extract was evaluated using HEp2 cell line. According to MTT analysis and probit analysis, the $\mathrm{CC}_{50}$ value of the crude extract on HEp2 cells was $97.66 \pm 11.4 \mu \mathrm{g} / \mathrm{mL}$. The analysis showed that the extract concentration was significantly related to cell death $(\mathrm{P}<0.01$, Figure 2).

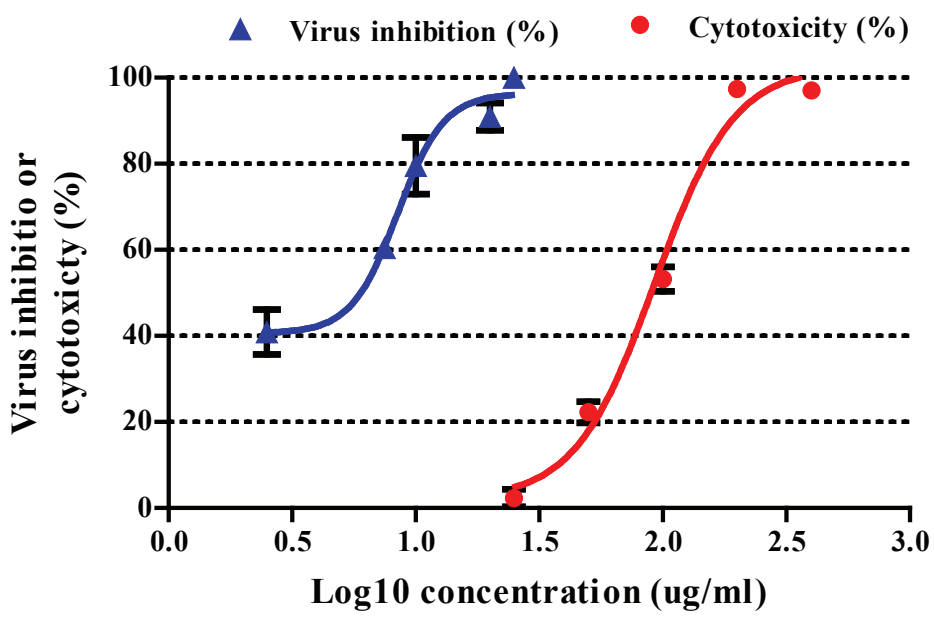

Figure 2. Anti-adenovirus activity and cytotoxicity of $S$. aromaticum extracts on HEp2 cells. Confluent HEp2 cells without virus or after adenovirus infection were exposed to different concentrations of the extract. Cell viability was measured with MTT assay.
HEp2 cells were inoculated with $100 \mathrm{TCID}_{50}(100 \mu \mathrm{L} /$ well $)$ of adenovirus for $2 \mathrm{~h}$ and were treated with various doses of the crude extract. Our findings showed that the more extract concentration, the more cytopathic effect (CPE) inhibition $(\mathrm{P}<0.05$, Figure 2). According to Probit analysis, $\mathrm{IC}_{50}$ of $S$. aromaticum extract on adenovirus was $4.73 \pm 1.62$ $\mu \mathrm{g} / \mathrm{mL}$. The SI value of the extract on adenovirus was 20.64 . Therefore, this extract seems to have noticeable activity against adenovirus.

Confluent HEp2 cells without virus or after adenovirus infection were exposed to different concentrations of the extract for 96h. Cell viability was measured in MTT assay. Experiences were carried out in triplicate.

\section{Mode of antiviral activity}

To evaluate the mode of antiviral action of the S. aromaticum extract, confluent monolayer cells were treated with the extract in four different manners; 1) pretreated prior to infection $2 \mathrm{~h}$ at $37^{\circ} \mathrm{C}$ (pretreatment of cell); 2) only during the adsorption period (adsorption); 3 ) after adsorption and until the completion of the experiment (post-adsorption); and 4) throughout and after of the adsorption (Figure 1). Based on the results, the $\mathrm{IC}_{50}$ value of the extract on adenovirus pre-treatment of cell, adsorption, post-adsorption, and throughout was $<97.66,24.42 \pm 3.62,4.73 \pm 1.62$ and $5 \pm 1.34$ and the selectivity index was $<1,3.99,20.64$ and 19.53 respectively. Our results showed that the inhibitory effect of the extract on adenovirus replication in HEp-2 cell line was greater in post-adsorption and during and after the

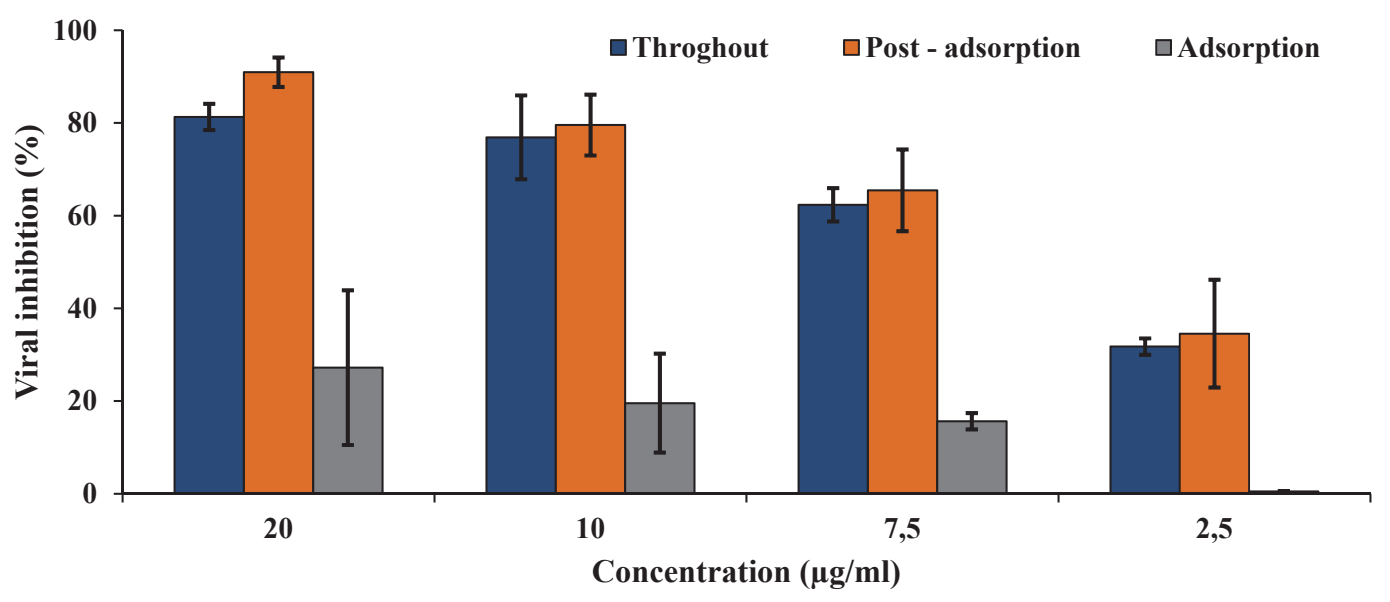

Figure 3. Inhibitory effect of $S$. aromaticum at different steps of adenovirus to HEp2 cells. Various concentrations of $S$. aromaticum extract were added carried out during the adsorption (adsorption), after adsorption until the completion of the experiment (post-adsorption), and during and after the treatment (throughout). After incubated cell viability was determined using MTT assay. The procedure was carried out three times." 
adsorption (throughout) than that of the other "treatment measurements" (Figure 3).

\section{Discussion}

In the present study, in vitro anti-adenovirus activity of $S$. aromaticum hydroalcoholic extract was evaluated using HEp2 cell line. According to our results, the CC50 value and the IC50 value of the extract (on adenovirus) were $99.66 \pm 11.4 \mu \mathrm{g} /$ $\mathrm{mL}$ and $4.73 \pm 1.62 \mu \mathrm{g} / \mathrm{mL}$, respectively. The SI value of the extract on adenovirus was 20.64. So, this extract seems to have noticeable activity against adenovirus. The recommended $\mathrm{IC}_{50}$ value, characteristic of herbal extract against infectious diseases is less than $100 \mu \mathrm{g} / \mathrm{mL}$ [36]. The extract used in this study revealed an $\mathrm{IC}_{50}$ value of $4.73 \pm 1.62 \mu \mathrm{g} / \mathrm{mL}$ which is far below the recommended cutoff. Total phenolic and flavonoid amounts of $S$. aromaticum extract was $255.8 \pm 3.95 \mathrm{mg} \mathrm{GAE} / \mathrm{g}$ and $63.9 \pm 2.35 \mathrm{mg}$ RUT/g respectively. Phenolic compounds have been shown to have antibacterial and anti-viral activities $[34,37-40]$. S. aromaticum is one of the richest sources of phenolic compounds such as gallic acid, eugenol and eugenol acetate [41]. One of these compounds, Eugenol (4-allyl1-hydroxy-2-methoxybenzene) has been shown to have antiviral activity against HSV-1 and HSV-2 virus replication in vitro $[42,43]$. The results of our study also showed that the $S$. aromaticum extract contained high level of phenolic compounds. Therefore, the anti-adenovirus activity of this extract could be attributed to its phenolic compounds such as eugenol.

To evaluate the antiviral mechanism of the extract against adenovirus, we also carried out pre-treatment of cell, during the adsorption (adsorption), after adsorption and until the completion of the experiment (post-adsorption), and during and after the adsorption (throughout). We observed that the antiviral effect of the $S$. aromaticum extract is more relevant to post-adsorption and during and after the adsorption (throughout) in comparison by other "treatment durations" on HEp-2 cell line. Based on our findings, the extract did not prevent the entry of adenovirus into HEp-2 cell, but it did act following penetration of the virus into the cell. Also, when extract was added to the cell culture before infection, did not effect on the adenovirus replication. Thus, the extract probably had no inhibitory effect on attachment of this virus to HEp-2 cell, but it did following penetration of the virus into this cell line.

The hydroalcoholic extract of $S$. aromaticum buds showed remarkable scavenging activity with $\mathrm{IC}_{50}$ values of $10.05 \pm 1.93$ $\mu \mathrm{g} / \mathrm{mL}$, as compared with synthetic antioxidants BHT with $\mathrm{IC}_{50}$ of $25.41 \pm 1.89 \mu \mathrm{g} / \mathrm{mL}$. They depend on phenol derivate compounds that obtained from extraction. Phenol compounds are essential constituent in plants and extract that containing much phenol has free radical scavenging activity is higher than other extracts [32,44-47].

\section{Conclusions}

Flower buds of Syzygium aromaticum L. extract with SI value of 20.64 against adenovirus and its capability of inhibiting the viral cycle, particularly throughout post-adsorption, can be considered a potential anti-adenovirus agent. Phenolic compounds have been shown to have antibacterial and antiviral activities. The results of this study also showed high level of these compounds in S. aromaticum extract. Hence, the antiviral activity of this plant might, in part, be attributed to phenolic compounds.

\section{Acknowledgments}

This work was funded by the Shahrekord University of Medical Science, Shahrekord, Iran (grant No.:1759). Authors are thankful to the Director of Medical Plants Research Center and the Deputy of Research and Technology of this university.

\section{References}

1. Karimi A, Hoseini SM. Seroprevalence of hepatitis B and C virus and HIV markers among blood donors from ShahreKord, Iran (2004-2006). Kuwait Med J 2008;40:285-7.

2. Karimi A, Imani-Rastabi R, Moezzi M, Moradi MT. Hepatitis a seroprevalence and associated risk factors: A community based cross-sectional study in Shahrekord, Iran. Arch Clin Infect Dis 2016;11:e32288.

3. Moezzi M, Imani R, Khosravi N, Pourheidar B, Ganji F, Karimi A. Hepatitis B seroprevalence and risk factors in adult population of chaharmahal and Bakhtiari Province in 2013. Hepat Mon 2014;14 :e17398.

4. Echavarria M. Adenoviruses in immunocompromised hosts. Clin Microbiol Rev 2008;21:704-15.

5. Lenaerts L, De Clercq E, Naesens L. Clinical features and treatment of adenovirus infections. Rev Med Virol 2008;18:357-74.

6. Calkavur S, Olukman O, Ozturk AT, Kilic FK, Gulfidan G, Devrim I, Malatyalı R, Oruc Y, Atlihan Y. Epidemic adenoviral keratoconjunctivitis possibly related to ophthalmological procedures in a neonatal intensive care unit: lessons from an outbreak. Ophthalmic Epidemiol 2012;19:371-9. 
7. Ersoy Y, Otlu B, Türkçüoğlu P, Yetkin F, Aker S, Kuzucu C. Outbreak of adenovirus serotype 8 conjunctivitis in preterm infants in a neonatal intensive care unit. J Hosp Infect 2012;80:144-9.

8. Ljungman P, Ribaud P, Eyrich M, Matthes-Martin S, Einsele H, Bleakley M, Machaczka M, Bierings M, Bosi A, Gratecos N, Cordonnier C; Infectious Diseases Working Party of the European Group for Blood and Marrow Transplantation. Cidofovir for adenovirus infections after allogeneic hematopoietic stem cell transplantation: A survey by the Infectious Diseases Working Party of the European Group for Blood and Marrow Transplantation. Bone Marrow Transplant 2003;31:481-6.

9. Yusuf U, Hale GA, Carr J, Gu Z, Benaim E, Woodard P, Kasow KA, Horwitz EM, Leung W, Srivastava DK, Handgretinger R, Hayden RT. Cidofovir for the treatment of adenoviral infection in pediatric hematopoietic stem cell transplant patients. Transplantation 2006;81:1398-404.

10. Hartline CB, Gustin KM, Wan WB, Ciesla SL, Beadle JR, Hostetler KY, Kern ER. Ether lipid-ester prodrugs of acyclic nucleoside phosphonates: Activity against adenovirus replication in vitro. J Infect Dis 2005;191:396-9.

11. Paolino K, Sande J, Perez E, Loechelt B, Jantausch B, Painter W, Anderson M, Tippin T, Lanier ER, Fry T, DeBiasi RL. Eradication of disseminated adenovirus infection in a pediatric hematopoietic stem cell transplantation recipient using the novel antiviral agent CMX001. J Clin Virol 2011;50:167-70.

12. Moradi MT, Asadi-Samani M, Bahmani M. Hypotensive medicinal plants according to ethnobotanical evidence of Iran: A systematic review. Int J Pharm Tech Res 2016;9:416-26.

13. Rafieian-Kopaei M, Sewell RD. The history and ups and downs of herbal medicines usage. J Herb Med Pharmacol 2014;3:1-3.

14. Asadi-Samani M, Moradi MT, Bahmani M, Shahrani M. Antiviral medicinal plants of Iran: A review of ethnobotanical evidence. Int J Pharm Tech Res 2016;9:427-34.

15. Karimi A, Mohammadi-Kamalabadi M, Rafieian-Kopaei M, Amjad L, Salimzadeh L. Determination of antioxidant activity, phenolic contents and antiviral potential of methanol extract of Euphorbia spinidens Bornm (Euphorbiaceae). Trop J Pharm Res 2016;15:759-64.

16. Mohammadi-Kamalabadi M, Karimi A, Rafieian M, Amjad L. Phytochemical study and anti viral effect evaluation of methanolic extract with fractions of aerial parts of Euphorbia spinidens. J Babol Univ Med Sci 2014;16:25-34.

17. Moradi MT, Gatreh-Samani K, Farrokhi E, Rafieian-Koupaei M, Karimi A. The effects of purslane (Portulaca oleracea L.) on serum level of lipids, lipoproteins and paraoxanase 1 (PON1) activity in hypercholesterolemia patients. Life Sci J 2012;9:5548-52.

18. Moradi MT, Karimi A, Alidadi S. In vitro antiproliferative and apoptosis-inducing activities of crude ethyle alcohole extract of Quercus brantii L. acorn and subsequent fractions. Chin J Nat Med 2016;14:196-202.

19. Moradi MT, Karimi A, Alidadi S, Ghasemi-Dehkordi P, Ghaffari-Goosheh MS. Cytotoxicity and in vitro antioxidant potential of Quercus brantii acorn extract and the corresponding fractions. Int J Pharmacogn Phytochem Res 2016;8:558-62.
20. Ahmad T, Shinkafi TS, Routray I, Mahmood A, Ali S. Aqueous extract of dried flower buds of Syzygium aromaticum inhibits inflammation and oxidative stress. J Basic Clin Pharm 2012;3:323-7.

21. Moradi MT, Rafieian-Koupaei M, Shahrani M. The effect of garlic methanol extract on gastric acid and pepsin in basic and stimulated conditions by electrical stimulus of vagus nerve in rats. Life Sci J 2013;10:99-104.

22. Asadi-Samani M, Kooti W, Aslani E, Shirzad H. A systematic review of Iran's medicinal plants with anticancer effects. J Evid Based Complementary Altern Med 2016;21:143-53.

23. Chaieb K, Hajlaoui H, Zmantar T, Kahla-Nakbi AB, Rouabhia M, Mahdouani K, Bakhrouf A. The chemical composition and biological activity of clove essential oil, Eugenia caryophyllata (Syzigium aromaticum L. Myrtaceae): A short review. Phytother Res 2007;21:501-6.

24. Zheng G-Q, Kenney PM, Lam LK. Sesquiterpenes from clove (Eugenia caryophyllata) as potential anticarcinogenic agents. J Nat Prod 1992;55:999-1003.

25. Tanaka T, Orii Y, Nonaka G, Nishioka I. Tannins and related compounds. CXXIII. Chromone, acetophenone and phenylpropanoid glycosides and their galloyl and/ or hexahydroxydiphenoyl esters from the leaves of Syzygium aromaticum MERR. et PERRY. Chem Pharm Bull 1993;41:1232-7.

26. Umehara K, Takagi R, Kuroyanagi M, Ueno A, Taki T, Chen Y-J. Studies on differentiation-inducing activities of triterpenes. Chem Pharm Bull 1992;40:401-5.

27. Farag R, Badei A, El Baroty G. Influence of thyme and clove essential oils on cottonseed oil oxidation. J Am Oil Chem Soc 1989;66:800-4.

28. Farag R, Badei A, Hewedi F, El-Baroty G. Antioxidant activity of some spice essential oils on linoleic acid oxidation in aqueous media. J Am Oil Chem Soc 1989;66:792-9.

29. Miyazawa M, Hisama M. Antimutagenic activity of phenylpropanoids from clove (Syzygium aromaticum). J Agric Food Chem 2003;51:6413-22.

30. Jadhav P, Kapoor N, Thomas B, Lal H, Kshirsagar N. Antiviral potential of selected Indian medicinal (ayurvedic) plants against herpes simplex virus 1 and 2. North Am J Med Sci 2012;4:641.

31. Moon J-H, Terao J. Antioxidant activity of caffeic acid and dihydrocaffeic acid in lard and human low-density lipoprotein. J Agric Food Chem 1998;46:5062-5.

32. Karimi A, Moradi M-T. Total phenolic compounds and in vitro antioxidant potential of crude methanol extract and the correspond fractions of Quercus brantii L. acorn. J Herb Med Pharmacol 2015;4:35-9.

33. Folin O, Ciocalteu V. On tyrosine and tryptophane determinations in proteins. J Biol Chem 1927;73:627-50.

34. Karimi A, Moradi MT, Alidadi S, Hashemi L. Anti-adenovirus activity, antioxidant potential, and phenolic content of black tea (Camellia sinensis Kuntze) extract. J Complement Integr Med 2016;13:357-63.

35. Mosmann T. Rapid colorimetric assay for cellular growth and survival: Application to proliferation and cytotoxicity assays. J Immunol Methods 1983;65:55-63. 
36. Cos P, Vlietinck AJ, Berghe DV, Maes L. Anti-infective potential of natural products: how to develop a stronger in vitro 'proof-of-concept'. J Ethnopharmacol 2006;106:290-302.

37. Balasubramanian P, Jayalakshmi K, Vidhya N, Prasad R, Sheriff AK, Kathiravan G, Rajagopal K, Sureban SM. Antiviral activity of ancient system of ayurvedic medicinal plant Cissus quadrangularis L. (Vitaceae). J Basic Clin Pharm 2009;1:37-40.

38. Moradi MT, Karimi A, Alidadi S, Saedi-Marghmaleki M. In vitro Anti-adenovirus activity of pomegranate (Punica granatum L.) peel extract. Adv Herbal Med 2015;1:1-8.

39. Moradi M-T, Rafieian-Kopaei M, Karimi A. A review study on the effect of Iranian herbal medicines against in vitro replication of herpes simplex virus. Avicenna J Phytomed 2016; 6: 506-15.

40. Karimi A, Rafieian-Kopaei M, Moradi MT, Alidadi S. Antiherpes simplex virus type- 1 activity and phenolic content of crude ethanol extract and four corresponding fractions of Quercus brantii L. acorn. J Evid Based Complementary Altern Med 2017;22: 455-66.

41. Karmakar S, Choudhury M, Das AS, Maiti A, Majumdar S, Mitra C. Clove (Syzygium aromaticum Linn) extract rich in eugenol and eugenol derivatives shows bone-preserving efficacy. Nat Prod Res. 2012;26:500-9.

42. Benencia F, Courreges M. In vitro and in vivo activity of eugenol on human herpesvirus. Phytother Res 2000;14:495500.

43. Cortés-Rojas DF, de Souza CRF, Oliveira WP. Clove (Syzygium aromaticum): A precious spice. Asian Pac J Trop Biomed 2014;4:90-6.

44. Akhlaghi M, Shabanian Gh, Rafieian-Koupaei M, Parvin N, Saadat M, Akhlaghi M. Citrus aurantium blossom and preoperative anxiety. Rev Bras Anestesiol 2011; 61:702-12.

45. Bahmani M, Sarrafchi A, Shirzad H, Rafieian-Kopaei M. Autism: Pathophysiology and promising herbal remedies. Curr Pharm Des 2016; 22:277-85.

46. Rafieian-Kopaei M, Baradaran A, Rafieian M. Oxidative stress and the paradoxical effects of antioxidants. J Res Med Sci 2013; 18: 628 .

47. Baradaran A, Nasri H, Nematbakhsh M, Rafieian-Kopaei M. Antioxidant activity and preventive effect of aqueous leaf extract of Aloe vera on gentamicin-induced nephrotoxicity in male Wistar rats. Clinica Terapeutica 2014;165:7-11. 